\title{
miRNA expression profile of vulvar squamous cell carcinoma and identification of the oncogenic role of miR-590-5p
}

\author{
XIUHUA YANG ${ }^{1}$ and XIN WU ${ }^{2}$ \\ Departments of ${ }^{1}$ Obstetrics and ${ }^{2}$ Gynaecology, The First Affiliated Hospital \\ of China Medical University, Shenyang, Liaoning 110001, P.R. China
}

Received July 25, 2015; Accepted September 17, 2015

DOI: $10.3892 /$ or.2015.4344

\begin{abstract}
MicroRNAs (miRNAs), a class of small non-coding RNA molecules, are associated with a variety of human cancers. Currently, little data are available regarding miRNA expression in vulvar squamous cell carcinoma (VSCC); the mechanism of action of miRNAs in VSCC still requires investigation. The aim of the present study was to investigate the miRNA expression profile in VSCC using a miRCURY ${ }^{\mathrm{TM}}$ LNA array. The expression levels of selected miRNAs were quantified by RT-qPCR. The relationship between miR-590-5p expression and clinical pathology was assessed. The expression levels of crucial transforming growth factor- $\beta$ (TGF- $\beta$ ) and Smad pathway factors were detected. We further investigated the role of miR-590-5p via in vitro studies in the A431 human VSCC cell line. A total of 157 miRNAs showed significantly altered expression in this type of carcinoma. Of particular interest, miR-590-5p, miR-182-5p and miR-183-5p were upregulated, and miR-603, miR-103a-3p and miR-107 were downregulated. A positive relationship was found between miR-590-5p expression and lymph node metastasis. In VSCC, TGF $\beta 1$ and TGF $\beta 2$ were significantly overexpressed and TGF $\beta$ RII and Smad4 were significantly underexpressed at both the RNA and protein levels. In A431 cells, overexpression of miR-590-5p promoted proliferation, migration and G1-S phase transition and downregulated TGF $\beta$ RII. The knockdown of TGF $\beta$ RII by siRNA promoted malignant behaviours in the A431 cells. In conclusion, we present the miRNA expression profile in VSCC, and our findings suggest that the upregulation of miR-590-5p promotes cellular malignant behaviours via the target gene TGF $\beta$ RII.
\end{abstract}

\section{Introduction}

Vulvar tumours constitute $4 \%$ of all gynaecological malignancies and are critical carcinomas of the female reproductive

Correspondence to: Dr Xin Wu, Department of Gynaecology, The First Affiliated Hospital of China Medical University, 155 Nanjing North Street, Shenyang, Liaoning 110001, P.R. China

E-mail: wuxin@mail.cmu.edu.cn

Key words: vulvar squamous cell carcinoma, miRNA, miR-590-5p, TGFßRII, microarray system (1). According to the National Cancer Institute, the incidence of vulvar cancer has increased in recent years in the US (2). The early diagnosis of vulvar cancer results in a five-year survival greater than $70 \%$. The prognosis of vulvar neoplasia depends on the clinical grade, tumour diameter and status of lymph node metastasis. Standard surgery can cause considerable morbidity and significant disfigurement. Patients require individualised therapy and less radical surgery to reduce the incidence of complications. At present, the majority of vulvar carcinomas are vulvar squamous cell carcinomas (VSCCs) (90\%) (3), and recent studies have shown that the overall incidence of VSCC has risen steadily at a rate of $20 \%$ over the past 40 years (4). Previous studies have not completely explained the aetiology of this disease. Thus, the identification of new tumour markers for the early detection and prognostic monitoring of VSCC remains urgently needed.

MicroRNAs (miRNAs) are short non-coding RNAs that silence mRNAs at the post-transcriptional levels. The transcription of approximately one-third of mRNAs is regulated by miRNAs, which are considered important regulators in key biological processes, such as cell growth, differentiation, adhesion, angiogenesis and inflammation (5-7). Changes in miRNA levels can cause different types of cancers. The miRNA expression profiles in cancer have been used to identify early diagnostic markers and therapeutic targets. At present, little data are available regarding miRNA expression in vulvar cancer. de Melo Maia et al (8) identified 79 miRNAs that showed markedly different expression levels in vulvar cancer compared with control samples. Although many miRNAs have been found to be associated with vulvar cancer, the mechanism of action of miRNAs in vulvar tumourigenesis still requires further investigation.

In the present study, we compared the miRNA expression profiles of VSCC and adjacent non-cancerous samples and investigated the mechanism of action of miR-590-5p in the A431 human VSCC cell line. The target of miR-590-5p was identified to elucidate the possible function of miR-590-5p in VSCC.

\section{Materials and methods}

Tissue collection. We obtained three pairs of freshly frozen VSCC samples and adjacent non-cancerous tissues for our microarray study (Table I). For miRNA analysis and target 
Table I. Characteristics of the patients in the microarray study.

\begin{tabular}{lcccc}
\hline $\begin{array}{l}\text { Sample } \\
\text { name }\end{array}$ & $\begin{array}{c}\text { Age } \\
\text { (years) }\end{array}$ & $\begin{array}{c}\text { FIGO } \\
\text { stage }\end{array}$ & $\begin{array}{c}\text { Tumor } \\
\text { differentiation }\end{array}$ & $\begin{array}{c}\text { Lymph node } \\
\text { metastasis }\end{array}$ \\
\hline A exp & 48 & IIIA & Moderate & Yes \\
a ctrl & 48 & - & - & - \\
B exp & 85 & IB & Well & No \\
b ctrl & 85 & - & - & - \\
F exp & 64 & IA & Well & No \\
f ctrl & 64 & - & - & - \\
\hline
\end{tabular}

gene validation step, 30 freshly frozen VSCC samples and adjacent non-cancerous tissues were collected. All of the tissues were obtained from the Department of Gynaecology at our hospital at the time of surgery between January 2011 and January 2015, and we snap-froze the samples rapidly for future use. We staged all of the lesions using the new vulvar cancer classification system (9). The pathology of the frozen specimens was analysed. Clinical records were retrospectively reviewed. We enrolled patients who had not undergone chemotherapy or radiation treatment prior to surgery. The Ethics Committee of the First Affiliated Hospital of China Medical University approved our research and we obtained the informed consent from patients.

miRNA microarray and bioinformatics. Kangchen Bio-tech Inc. (Shanghai, China) extracted the total RNA from the tissue samples and performed our microarray analysis using a miRCURY ${ }^{\mathrm{TM}}$ LNA array (v.18.0; Exiqon). After carefully reviewing the literature, we chose 25 upregulated and 25 downregulated miRNAs for further study. Three web-based miRNA target prediction programs were used to explore potential target genes: TargetScan (https://www.targetscan.org/vert 60/), MicroCosm (http://www.ebi.ac.uk/enright-srv/microcosm/htdocs/targets/v5/) and miRanda (http://www.microrna. org/microrna/home.do). To improve the accuracy of our results, we further examined the putative genes that were identified by the three algorithms for further study. We conducted Gene Ontology (GO) and KEGG pathways analyses on these target genes.

Real-time quantitative PCR of miRNAs. We selected fragments of the differentially expressed miRNAs for further verification in 30 additional VSCC tissues and the corresponding adjacent non-cancerous vulvar samples. Total RNA was isolated from tissues using TRIzol reagent (Invitrogen Life Technologies, Carlsbad, CA, USA) according to the manufacturer's instructions. As previously described (10), we applied stem-loop RT-PCR to detect the miRNA levels. cDNA synthesis was performed using a Gene Amp PCR System 9700 (Applied Biosystems, Foster City, CA, USA). We performed RT-qPCR in triplicate following standard protocols. We calculated the miRNA expression levels using the $2^{-\Delta \Delta \mathrm{Ct}}$ method with U6 as the internal control. The PCR cycle parameters were the following: $95^{\circ} \mathrm{C}$ for $10 \mathrm{~min}$ followed by 40 cycles of $95^{\circ} \mathrm{C}$ for $10 \mathrm{sec}$ and $60^{\circ} \mathrm{C}$ for $60 \mathrm{sec}$. The miRNA primers are shown in Table II.
Detection of $m$ RNAs of TGF $\beta 1, T G F \beta 2, T G F \beta R I I$ and Smad4. We detected mRNAs of TGF $\beta 1$, TGF $\beta 2$, TGF $\beta$ RII and Smad4 in the tissue samples by RT-qPCR. We quantified the amplified products using the SYBR-Green method (Takara Bio, Inc., Dalian, China) with GAPDH as the internal control. The fold-changes were quantified using the $2^{-\Delta \Delta C t}$ method. The primers were as follows: GAPDH forward, AAGGTGAAGG TCGGAGTCAAC and reverse, GGGTCATTGATGGCAAC AATA; TGF $\beta 1$ forward, AAGGACCTCGGCTGGAAGTG and reverse, CCCGGGTTATGCTGGTTGTA; TGF $\beta 2$ forward, TGCCGCCCTTCTTCCCCTC and reverse, GGAG CACAAGCTGCCCACTGA; TGF $\beta$ RII forward, AAGATGA CCGCTCTGACATCA and reverse, CTTATAGACCTCAGC AAAGCGAC; and Smad4 forward, CGCTTTTGTTTGGGT CAACT and reverse, CCCAAACATCACCTTCACCT. The RT-qPCR parameters were the following: $95^{\circ} \mathrm{C}$ for $10 \mathrm{~min}$ followed by 40 cycles of $95^{\circ} \mathrm{C}$ for $5 \mathrm{sec}$ and $60^{\circ} \mathrm{C}$ for $34 \mathrm{sec}$.

Western blotting. The total protein from the tissue samples and cells was prepared for western blot analysis. Seventy-two hours after transfection with the miRNA mimics or siRNA-TGF $\beta$ RII, the total protein was collected for analysis (11). Immunoblotting was performed with monoclonal TGF $\beta 1$ (ab64715) $(1: 1,000)$, polyclonal TGF $\beta 2$ (ABE586; cat.) (1:1,000), polyclonal TGFßRII (ab78419) (1:1,000), monoclonal Smad4 (ab40759) $(1: 5,000)$ or GAPDH (ab181602) $(1: 5,000)$ antibody (all from Abcam, Cambridge, MA, USA). The membrane was washed and incubated with goat anti-rabbit (1:5,000; Invitrogen Life Technologies) or anti-mouse $\operatorname{IgG}(\mathrm{H}+\mathrm{L})$-HRP conjugate (1:10,000; Invitrogen Life Technologies) antibody. The ImageJ software was used to determine the relative protein expression levels.

Cell culture and transfection. The A431 cell line was obtained from ATCC (Manassas, VA, USA) and cultured in RPMI-1640 medium containing $10 \%$ fetal bovine serum under standard conditions at $37^{\circ} \mathrm{C}$ and $5 \% \mathrm{CO}_{2}$ in a humidified atmosphere. The cells were transfected with Dharmacon miRIDIAN miR-590-5p mimic (miR-590-5p) and the negative control (Thermo Fisher Scientific, Lafayette, CO, USA) at a final concentration of $100 \mathrm{nmol} / \mathrm{l}$. A small interfering RNA targeting TGF $\beta$ RII (siRNA-TGF $\beta$ RII) was obtained from Santa Cruz Biotechnology, Inc. (Santa Cruz, CA, USA) (sc-36657). The cells were transfected using Lipofectamine 2000 (Invitrogen Life Technologies) according to the manufacturer's recommendation.

MTT assay. We performed an MTT assay to evaluate cell proliferation. A431 cells were plated in 96-well sample culture plates at a density of $5 \times 10^{4}$ cells per well with the miR-590-5p mimics or siRNA-TGF $\beta$ RII and the corresponding negative controls. The cells were cultured for 48 and $96 \mathrm{~h}$, and the optical absorbance was read at $490 \mathrm{~nm}$ on a microplate reader. The experiments were conducted in triplicate.

Cell migration. A Transwell assay was performed to examine cell migration. Forty-eight hours after transfection, $5 \times 10^{4}$ cells were placed in the upper chambers of Transwell plates with an untreated membrane. After $24 \mathrm{~h}$ of incubation, the chambers were treated with $4 \%$ paraformaldehyde and then fixed 
Table II. Primers used in reverse transcription and real-time PCR for the miRNAs.

\begin{tabular}{llc}
\hline Gene & Reverse transcriptase reaction primer (5' to 3') & Real-time quantitative PCR primer (5' to 3') \\
\hline U6 & CGCTTCACGAATTTGCGTGTCAT & F: GCTTCGGCAGCACATATACTAAAAT \\
miR-590-5p & R: CGCTTCACGAATTGCGTGTCAT \\
& GTCGTATCCAGTGCGTGTCGTGGAGTC & GSP: GGGGGAGCTTATTCATAAAA \\
miR-182-5p & GGCAATTGCACTGGATACGACCTGCAC & R: CAGTGCGTGTCGTGGAGT \\
& GTCGTATCCAGTGCGTGTCGTGGAGTC & GSP: GGGTTTGGCAATGGTAGAAC \\
miR-183-5p & GGCAATTGCACTGGATACGACAGTGTG & R: CAGTGCGTGTCGTGGAGT \\
& GTCGTATCCAGTGCGTGTCGTGGAGTC & GSP: GGGTATGGCACTGGTAGAATT \\
miR-603 & GGCAATTGCACTGGATACGACAGTGAA & R: CAGTGCGTGTCGTGGAGT \\
& GTCGTATCCAGTGCGTGTCGTGGAGTC & GSP: CACACACTGCAATTACTTTTGC \\
miR-103a-3p & GGCAATTGCACTGGATACGACGCAAAA & R: CAGTGCGTGTCGTGGAGT \\
miR-107 & GTCGTATCCAGTGCGTGTCGTGGAGTC & GSP: AGCAGCATTGTACAGGGCTA \\
& GGCAATTGCACTGGATACGACTCATAG & R: CAGTGCGTGTCGTGGAGT \\
& GTCGTATCCAGTGCGTGTCGTGGAGTC & GSP: AGCAGCATTGTACAGGGCTA \\
& GGCAATTGCACTGGATACGACTGATAG & R: CAGTGCGTGTCGTGGAGT \\
\hline
\end{tabular}

with hematoxylin and eosin. The cells that passed through the membrane were counted. The migration assays were conducted in triplicate.

Analysis of cell cycle distribution. Cells transfected with the miR-590-5p mimics or siRNA-TGF $\beta$ RII for $48 \mathrm{~h}$ were collected and placed in ethanol $(70 \%)$ for $24 \mathrm{~h}$. The cells were then treated with propidium iodide $(40 \mu \mathrm{g} / \mathrm{ml})$ for $30 \mathrm{~min}$. Flow cytometry was used for the analysis, and the experiments were performed in triplicate.

Statistical analysis. The data are presented as the means \pm SD, and SPSS 15.0 software (SPSS, Inc., Chicago, IL, USA) was used for all of the data analyses. The significance of differences in the mean values was analysed using the Student's t-test. A two-sided Fisher's exact test was used to determine the relationship between miR-590-5p expression and clinicopathological data. $\mathrm{P}<0.05$ was considered to indicate a statistically significant difference.

\section{Results}

miRNA expression profile in VSCC. After confirming the quality of the RNA extracted from the tissue samples, we determined the miRNA expression profile of VSCC. We selected the miRNAs that were overexpressed or underexpressed by more than 2-fold for the bioinformatics analysis and identified 90 upregulated and 67 downregulated miRNAs in the cancer samples (Fig. 1, Tables III and IV).

Bioinformatics. In total, 1,350 genes were predicted. GO analysis and KEGG annotation showed that the transforming growth factor- $\beta$ (TGF- $\beta$ ) pathway was an enriched pathway in VSCC (Fig. 2).

Confirmation of the microarray findings. To confirm our microarray findings, RT-qPCR analysis of miR-590-5p, miR-182-5p, miR-183-5p, miR-603, miR-103a-3p and miR-107 was conducted. The RT-qPCR results were in accordance with the microarray results (Fig. 3): in VSCC, miR-590-5p, miR-182-5p and miR-183-5p were upregulated, and miR-603, miR-103a-3p and miR-107 were downregulated.

Relationship between miR-590-5p and clinical pathology of vulvar cancer. We set the 75 th percentile of the $2^{-\Delta \Delta \mathrm{Ct}}$ values as the cut-off value for samples with high or low levels of miR-590-5p (12). The miR-590-5p level was not correlated with patient age, tumour differentiation, vascular invasion, FIGO stage, tumour size and depth of invasion but was positively correlated with lymph node metastasis $(\mathrm{P}=0.009)$ (Table V). The results indicated that increased expression of miR-590-5p aids the distant spread of VSCC.

Putative target genes. According to the target prediction programs, TGF $\beta 1$ and TGF $\beta 2$ are both putative target genes for miR-590-5p (Table VI), TGF $\beta$ RII is a target of miR-590-5p in human hepatocellular carcinoma (13), and miR-182-5p acts as an oncogene by knocking down Smad4 in bladder cancer (14). Since the results showed that miR-182-5p and miR-590-5p were upregulated in VSCC (Fig. 3), we detected the mRNA and protein levels of TGF $\beta 1$, TGF $\beta 2$, TGF $\beta$ RII and Smad4. The RNA levels of TGF $\beta 1$ and TGF $\beta 2$ were significantly overexpressed in VSCC compared with control tissues by 2.95 -fold and 3.25-fold, respectively (Fig. 4A). The protein levels of TGF $\beta 1$ and TGF $\beta 2$ were found to be markedly increased in VSCC (Fig. 4B and C). The RNA levels of TGF $\beta$ RII and Smad4 were significantly underexpressed in VSCC compared with control tissues by 0.21 -fold and 0.25 -fold, respectively (Fig. 4A), and the protein levels of TGF $\beta$ RII and Smad4 were markedly decreased in VSCC (Fig. 4B and C). Based on our results and the literature (13), we hypothesized that TGF $\beta$ RII is a target gene of miR-590-5p in VSCC.

miR-590-5p promotes the proliferation, migration and the G1-to-S transition in A431 cells. A431 cells were transiently transfected with the miR-590-5p mimic at a 


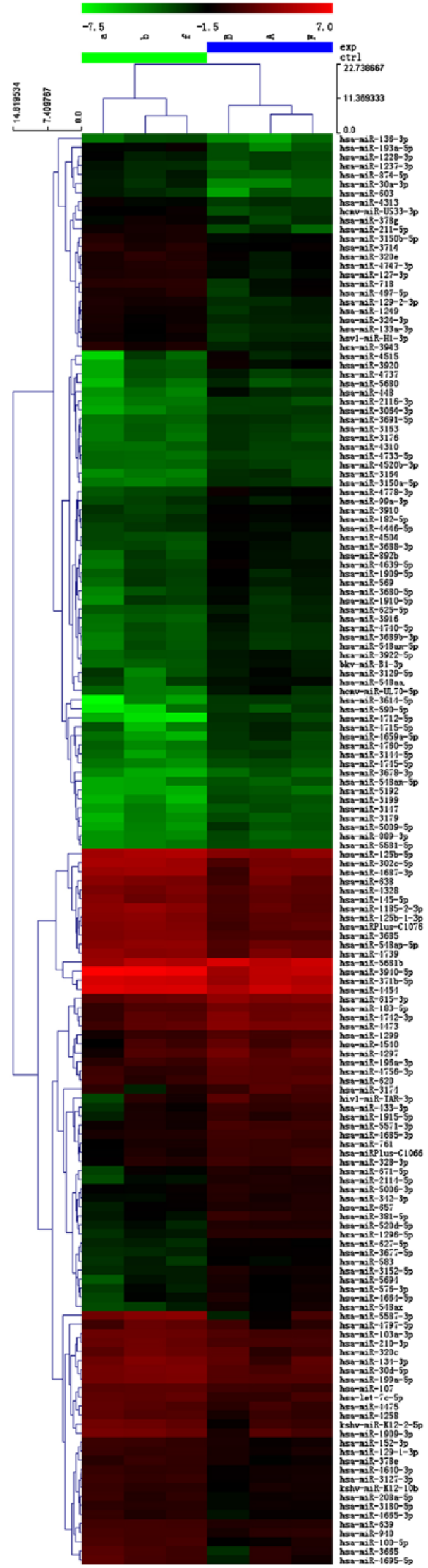

concentration of $100 \mathrm{nM}$. At $96 \mathrm{~h}$, the proliferation rate of the A431 cells transfected with the miR-590-5p mimic was markedly higher $(\mathrm{P}=0.001)$ than that of the cells transfected with the miRNA negative control (Fig. 5D). The miR-590-5p mimic significantly promoted A431 cell migration. The migration rate of the cells transfected with the miR-590-5p mimics was $40 \%$ higher than that of the cells transfected with the negative control ( $\mathrm{P}=0.001)$ (Fig. 6A). An analysis of the cell cycle distribution by flow cytometry showed that the percentage of A431 cells in the G1 phase was significantly decreased from $58.89 \pm 1.69 \%$ before transfection to $47.73 \pm 1.23 \%$ at $48 \mathrm{~h}$ after transfection $(\mathrm{P}=0.001)$ and that the percentage of cells in the $\mathrm{S}$ phase was significantly increased from $27.80 \pm 1.95 \%$ before transfection to $43.41 \pm 1.22 \%$ at $48 \mathrm{~h}$ after transfection $\left(\mathrm{P}=2.998 \times 10^{-4}\right)$ (Fig. 7A).

Knockdown of TGF $\beta$ RII increases the proliferation and migration of vulvar carcinoma cells. We used an siRNA that targets TGF $\beta$ RII (siR-TGF $\beta$ RII) to investigate the role of TGF $\beta$ RII in the proliferation and migration of A431 cells. Forty-eight hours after the knockdown of TGF $\beta$ RII in the A431 cells, the mRNA and protein expression levels of TGF $\beta$ RII were reduced by $60.3 \pm 3.5 \%(\mathrm{P}=0.001)$ (Fig. $8 \mathrm{~A})$ and $57.7 \pm 3.2 \%(\mathrm{P}=0.001)$ (Fig. 8B and $\mathrm{C}$ ), respectively. TGF $\beta \mathrm{RII}$ knockdown markedly decreased the percentage of A431 cells in the G1 phase from $57.05 \pm 1.26 \%$ before knockdown to $49.62 \pm 1.84 \%$ at $48 \mathrm{~h}$ after knockdown $(\mathrm{P}=0.005)$ (Fig. $7 \mathrm{~B})$ and promoted cell proliferation $(\mathrm{P}=0.003)$ (Fig. 8D) and cell migration ( $\mathrm{P}=0.008)$ (Fig. 6B).

miR-590-5p targets TGF $\beta R I I$. In the A431 cells, TGF $\beta$ RII expression was significantly downregulated by the forced expression of miR-590-5p. TGF $\beta$ RII mRNA expression was decreased by $28.7 \pm 6.8 \%(\mathrm{P}=0.018)$ and TGF $\beta R$ II protein expression was decreased by $37.7 \pm 5.1 \%(\mathrm{P}=0.006)$ in the cells transfected with miR-590-5p compared to the cells transfected with the miRNA negative control (Fig. 5A-C).

\section{Discussion}

miRNAs are highly conserved small RNA molecules (18-24 bp in length) that block translation or promote mRNA degradation. Researchers use miRNA expression profiles to identify new early diagnostic markers and key pathways that are relevant to cancer and to predict outcomes (15). However, few miRNA studies have focused on VSCC. In the present study, we determined the miRNA expression profile of VSCC using a miRCURY ${ }^{\mathrm{TM}}$ LNA array. To confirm the reproducibility of the experiment, we determined the expression levels of 6 miRNAs in 30 pairs of tissues by RT-qPCR and found that the results of the two assays were consistent. This investigation of the miRNA profile of VSCC provides valuable information regarding the aetiology of VSCC. Computational approaches, such as GO and KEGG, provide high statistical power for confirming the biological relevance of the experimental data. Using bioinformatics, we

Figure 1. miRNA expression in VSCC as determined by microarray. Each row represents an miRNA and each column represents a sample. Green indicates low relative expression and red indicates high relative expression. 
Table III. miRNAs with a 2-fold increased change in VSCC.

\begin{tabular}{|c|c|c|c|c|c|}
\hline Name & $\begin{array}{l}\text { Fold-change } \\
\text { (exp vs. ctrl) }\end{array}$ & $\begin{array}{c}\text { P-value } \\
\text { (exp vs. ctrl) }\end{array}$ & Name & $\begin{array}{l}\text { Fold-change } \\
\text { (exp vs.ctrl) }\end{array}$ & $\begin{array}{c}\text { P-value } \\
\text { (exp vs. ctrl) }\end{array}$ \\
\hline hsa-miR-1909-5p & 2.268009207 & 0.034970206 & hsa-miR-4685-3p & 2.073555353 & 0.036241143 \\
\hline hsa-miR-625-5p & 2.299905838 & 0.016908005 & hsa-miR-4740-5p & 2.38994988 & 0.022891232 \\
\hline hsa-miR-3680-5p & 2.874185596 & 0.031517055 & hsa-miR-342-3p & 2.181671493 & 0.035571011 \\
\hline hsa-miR-5006-3p & 2.041647823 & 0.040961217 & hsa-miR-657 & 2.134615186 & 0.007542585 \\
\hline hsa-miR-448 & 4.877156933 & 0.047126944 & hsa-miR-520d-5p & 3.073773663 & 0.000401222 \\
\hline hsa-miR-3179 & 2.787311058 & 0.000743429 & hsa-miR-4659a-5p & 4.519405061 & 0.022666827 \\
\hline hsa-miR-548am-5p & 2.766300414 & 0.015495713 & hsa-miR-4756-3p & 2.247748775 & 0.037541024 \\
\hline hsa-miR-548au-5p & & & hsa-miR-4715-5p & 3.419119082 & 0.005577942 \\
\hline hsa-miR-548c-5p & & & hsa-miR-548am-5p & 2.214394005 & 0.007252986 \\
\hline hsa-miR-548o-5p & & & hsa-miR-548c-5p & & \\
\hline hsa-miR-5571-3p & 2.856577623 & 0.005585384 & hsa-miR-548o-5p & & \\
\hline hsa-miR-4760-5p & 2.448261646 & 0.04027403 & hsa-miR-576-3p & 2.244314801 & 0.01432112 \\
\hline hsa-miR-3614-5p & 5.742156538 & 0.01292475 & hsa-miR-196a-3p & 2.372627688 & 0.004993835 \\
\hline hsa-miR-4737 & 2.530840607 & 0.038784823 & hsa-miR-671-5p & 2.537177995 & 0.009026734 \\
\hline hsa-miR-892b & 2.858771178 & 0.017431678 & hsa-miR-3176 & 2.203589711 & 0.029281769 \\
\hline hsa-miR-4639-5p & 3.240730738 & 0.032308547 & hsa-miR-3147 & 2.735734119 & 0.047108881 \\
\hline hsa-miR-627-5p & 2.052727495 & 0.0037273 & hsa-miR-3910 & 2.608801926 & 0.015245264 \\
\hline hsa-miR-183-5p & 2.419287261 & 0.013326849 & hsa-miR-4733-5p & 2.008593535 & 0.007370313 \\
\hline hsa-miR-4778-3p & 3.699981341 & 0.025561685 & hsa-miR-4520b-3p & 2.017026584 & 0.047310787 \\
\hline hsa-miR-3129-5p & 2.781924851 & 0.008224854 & hsa-miR-4712-5p & 12.22863711 & 0.014670128 \\
\hline hsa-miR-2116-3p & 2.84569609 & 0.046005427 & hsa-miR-4446-5p & 2.134631842 & 0.004281929 \\
\hline hsa-miR-99a-3p & 2.078061984 & 0.02427523 & hsa-miR-889-3p & 2.399358429 & 0.041746801 \\
\hline hsa-miR-3163 & 2.236794583 & 0.019324673 & hsa-miR-583 & 2.027782059 & 0.049386185 \\
\hline hsa-miR-4515 & 4.005941261 & 0.043115779 & hsa-miR-3678-3p & 2.766474628 & 0.021131864 \\
\hline hsa-miR-761 & 2.283378294 & 0.030433155 & hsa-miR-3164 & 3.639623557 & 0.044721554 \\
\hline hiv1-miR-TAR-3p & 3.407407279 & 0.042298704 & hsa-miR-3688-3p & 2.833806324 & 0.027287514 \\
\hline hsa-miR-3916 & 3.177438789 & 0.04565907 & hsa-miR-433-3p & 2.956586285 & 0.005371443 \\
\hline hsa-miR-5694 & 2.530767474 & 0.01283172 & hsa-miR-3922-5p & 3.02440681 & 0.034490467 \\
\hline hsa-miR-3152-5p & 2.654922182 & 0.037278832 & hsa-miR-2114-5p & 3.239366725 & 0.031005786 \\
\hline hsa-miR-182-5p & 2.333439033 & 0.026694345 & hsa-miRPlus-C1066 & 2.469174691 & 0.016399394 \\
\hline hsa-miR-569 & 2.407604243 & 0.024602814 & hsa-miR-1915-5p & 2.208897579 & 0.001720096 \\
\hline hsa-miR-381-5p & 3.635872619 & 0.023950604 & hsa-miR-3064-3p & 3.469771706 & 0.005127139 \\
\hline hsa-miR-4310 & 2.232312931 & 0.047107543 & bkv-miR-B1-3p & 3.418831807 & 0.018095363 \\
\hline hsa-miR-3677-5p & 2.132387267 & 0.003261066 & jcv-miR-J1-3p & & \\
\hline hsa-miR-5192 & 3.677159629 & 0.044010016 & hsa-miR-5681b & 2.021948002 & 0.034047499 \\
\hline hsa-miR-5680 & 2.575312372 & 0.032441222 & hsa-miR-4664-5p & 2.119244868 & 0.031194048 \\
\hline hsa-miR-4504 & 2.717320696 & 0.014710469 & hsa-miR-3150a-5p & 3.134068744 & 0.028284216 \\
\hline hsa-miR-1299 & 2.002702571 & 0.013834637 & hsa-miR-1296-5p & 4.088863472 & 0.003660659 \\
\hline hsa-miR-1910-5p & 2.162735851 & 0.03783251 & hsa-miR-3144-5p & 2.926516532 & 0.022729536 \\
\hline hsa-miR-3689b-3p & 2.415977652 & 0.017534668 & hsa-miR-4745-5p & 2.466356986 & 0.000146798 \\
\hline hsa-miR-3689c & & & hsa-miR-4473 & 2.504250002 & 0.034469781 \\
\hline hsa-miR-3920 & 5.625452236 & 0.026111532 & hsa-miR-548aa & 2.835267551 & 0.009012684 \\
\hline hsa-miR-3199 & 4.295820524 & 0.000563038 & hsa-miR-548t-3p & & \\
\hline hsa-miR-4540 & 2.012988685 & 0.016275315 & hcmv-miR-UL70-5p & 4.45206206 & 0.049288866 \\
\hline hsa-miR-5009-5p & 3.71180521 & 0.040632129 & hsa-miR-328-3p & 2.116531252 & 0.005483732 \\
\hline hsa-miR-615-3p & 2.483195697 & 0.044667033 & hsa-miR-4297 & 2.255154322 & 0.033062969 \\
\hline hsa-miR-590-5p & 5.021381531 & 0.023268648 & hsa-miR-620 & 2.159044023 & 0.040631617 \\
\hline hsa-miR-3174 & 2.939705901 & 0.029182617 & hsa-miR-5581-5p & 2.215694094 & 0.036348099 \\
\hline hsa-miR-3691-5p & 2.345199113 & 0.024231387 & hsa-miR-548ax & 3.255292172 & 0.020722488 \\
\hline
\end{tabular}

Table III. Continued. 
Table IV. miRNAs with a 2-fold decreased change in VSCC.

\begin{tabular}{|c|c|c|}
\hline Name & $\begin{array}{l}\text { Fold-change } \\
\text { (exp vs. ctrl) }\end{array}$ & $\begin{array}{c}\text { P-value } \\
\text { (exp vs. ctrl) }\end{array}$ \\
\hline hsa-miR-103a-3p & 0.424280671 & 0.004572105 \\
\hline hsa-miR-125b-1-3p & 0.312927645 & 0.038777049 \\
\hline hsa-miR-4475 & 0.461365437 & 0.025426598 \\
\hline hsa-miR-4640-3p & 0.44007417 & 0.008555965 \\
\hline kshv-miR-K12-2-5p & 0.261405403 & 0.031752834 \\
\hline hsa-miR-136-3p & 0.469715785 & 0.047488345 \\
\hline hsa-miRPlus-C1076 & 0.336815427 & 0.039990317 \\
\hline hsa-miR-4313 & 0.434091658 & 0.030820428 \\
\hline hsa-miR-125b-5p & 0.435287519 & 0.010836626 \\
\hline hsa-miR-718 & 0.301243354 & 0.008612888 \\
\hline hsa-miR-3665 & 0.306037784 & 0.044793295 \\
\hline hsa-miR-3150b-5p & 0.491060897 & 0.035735777 \\
\hline hsa-miR-152-3p & 0.419871509 & 0.028451985 \\
\hline hsa-miR-638 & 0.447432966 & 0.018664434 \\
\hline hsa-miR-639 & 0.495992306 & 0.003366715 \\
\hline hsa-miR-4747-3p & 0.400747519 & 0.00664862 \\
\hline hsa-miR-302c-5p & 0.267763813 & 0.024743292 \\
\hline hsa-miR-1228-3p & 0.431370899 & 0.040648229 \\
\hline hcmv-miR-US33-3p & 0.329650196 & 0.007069712 \\
\hline hsa-miR-3127-3p & 0.39249684 & 0.005878926 \\
\hline hsa-miR-548ap- & 0.374250134 & 0.03201148 \\
\hline \multicolumn{3}{|l|}{ 5p/hsa-miR-548j-5p } \\
\hline hsa-miR-1249 & 0.369524954 & 0.028701441 \\
\hline hsa-miR-210-3p & 0.451024778 & 0.015191447 \\
\hline hsa-miR-3714 & 0.455539333 & 0.047728424 \\
\hline hsa-miR-1185-2-3p & 0.280261944 & 0.035995727 \\
\hline hsa-miR-320e & 0.424891032 & 0.018026801 \\
\hline hsa-miR-378g & 0.422359181 & 0.01182177 \\
\hline hsa-miR-3180-5p & 0.467975782 & 0.010146089 \\
\hline hsa-miR-4797-5p & 0.34170329 & 0.042345844 \\
\hline hsa-miR-320c & 0.458391368 & 0.012703414 \\
\hline hsa-miR-127-3p & 0.391036192 & 0.002697576 \\
\hline hsa-miR-129-1-3p & 0.484901627 & 0.033744514 \\
\hline hsa-miR-193a-5p & 0.211752847 & 0.020608715 \\
\hline hsa-miR-107 & 0.491113228 & 0.00909686 \\
\hline hsa-miR-1237-3p & 0.491995661 & 0.025161672 \\
\hline hsa-miR-129-2-3p & 0.326940269 & 0.017236448 \\
\hline hsa-miR-378e & 0.432741045 & 0.004039221 \\
\hline hsa-miR-30d-5p & 0.399892004 & 0.003032197 \\
\hline hsa-miR-940 & 0.497089979 & 0.01686806 \\
\hline hsa-miR-3685 & 0.281450369 & 0.007545584 \\
\hline hsa-miR-497-5p & 0.377350451 & 0.011166099 \\
\hline hsa-miR-208a-5p & 0.407300528 & 0.035579721 \\
\hline hsa-miR-3940-5p & 0.22946766 & 0.026666441 \\
\hline hsa-miR-30a-3p & 0.246337873 & 0.018149941 \\
\hline kshv-miR-K12-10b & 0.489194522 & 0.01863871 \\
\hline hsa-miR-211-5p & 0.209335232 & 0.027658562 \\
\hline hsa-miR-133a-3p & 0.353621363 & 0.025055885 \\
\hline hsa-let-7c-5p & 0.420424499 & 0.004476239 \\
\hline hsa-miR-4328 & 0.481358306 & 0.016905376 \\
\hline hsa-miR-4258 & 0.379569936 & 0.006127006 \\
\hline
\end{tabular}

Table IV. Continued.

\begin{tabular}{llc}
\hline Name & $\begin{array}{l}\text { Fold-change } \\
\text { (exp vs. ctrl) }\end{array}$ & $\begin{array}{c}\text { P-value } \\
\text { (exp vs. ctrl) }\end{array}$ \\
\hline hsa-miR-874-5p & 0.381710238 & 0.029590223 \\
hsa-miR-134-3p & 0.427828419 & 0.012731845 \\
hsa-miR-4665-3p & 0.386183592 & 0.029972291 \\
hsa-miR-324-3p & 0.408704049 & 0.042361639 \\
hsv1-miR-H1-3p & 0.414986507 & 0.016595063 \\
hsa-miR-199a-5p & 0.419753002 & 0.010205226 \\
hsa-miR-603 & 0.337203781 & 0.036655296 \\
hsa-miR-1909-3p & 0.331046605 & 0.043830752 \\
hsa-miR-3943 & 0.331748922 & 0.034720544 \\
hsa-miR-4687-3p & 0.322418396 & 0.049090253 \\
hsa-miR-145-5p & 0.438537269 & 0.042746741 \\
hsa-miR-100-5p & 0.274313719 & 0.013542083 \\
hsa-miR-371b-5p & 0.440758217 & 0.019114517 \\
hsa-miR-5587-3p & 0.115849457 & 0.023669599 \\
hsa-miR-4739 & 0.432716062 & 0.004950109 \\
hsa-miR-4454 & 0.48752685 & 0.005377393 \\
hsa-miR-4695-5p & 0.276772972 & 0.037591238 \\
\hline
\end{tabular}

found that the TGF $\beta$ signalling pathway is important in VSCC. The RNA and protein levels of key factors (TGF $\beta 1$, TGF $\beta 2$, TGF $\beta$ RII and Smad4) were measured in tissue samples, and TGF $\beta$ RII was selected for further research.

We observed the upregulation of miR-590-5p in VSCC. miR-590-5p has been reported to increase cardiac muscle cell growth in mammals (16) and has frequently been shown to be upregulated in tumours, which suggests that miR-590-5p promotes tumour progression. miR-590-5p has been shown to be overexpressed in patients with high-risk types of Wilms' carcinoma (17). The target mRNAs of miR-590-5p have been identified in certain studies. For example, miR-590-5p has been shown to exert oncogenic activity through targeting of the CHL1 gene in cervical carcinoma (18). In addition, upregulation of miR-590-5p has been shown to be induced by the downregulation of PBRM1 in renal cancer cell lines (19). Another research group showed that miR-590 is upregulated by TGF $\beta$ RII in cardiosphere-derived cells during differentiation (20). However, Shan et al reported that miR-590-5p is downregulated in liver cancer and that miR-590-5p decreases the proliferation of carcinoma cells by targeting S100A100 (21). Our study showed that miR-590-5p is overexpressed in vulvar cancer tissues (Fig. 3). Thus, miR-590-5p may be a novel oncogenic miRNA in VSCC.

Our research also showed that TGF $\beta$ RII is negatively regulated by miR-590-5p in VSCC. The TGF- $\beta / \mathrm{Smad}$ signalling pathway functions as an important regulator of the pathogenesis of many cancers, including colon cancer, oesophageal squamous cell carcinoma, breast cancer and lung cancer (22-25). Many studies have investigated the effect of TGF- $\beta$ /Smad signalling on epithelial cell proliferation and carcinoma. In humans, the three TGF $\beta$ isoforms, TGF $\beta 1$, TGF $\beta 2$ and TGF $\beta 3$, exhibit high similarity and homology. The TGF- $\beta$ pathway transfers signals to the inside of cells via 


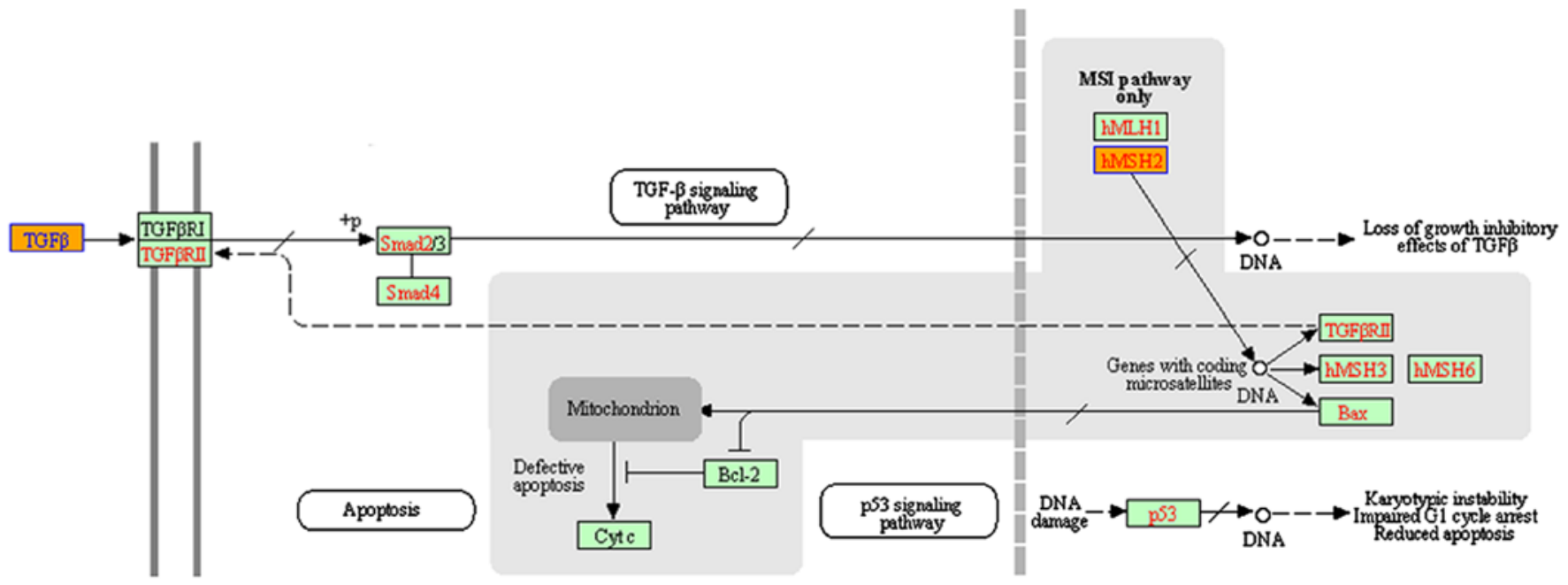

Figure 2. Relationship of the TGF- $\beta$ signalling pathway to VSCC. The orange nodes indicate putative target genes of the miRNAs that were found to be differentially expressed in VSCC, and the green nodes indicate genes in the TGF- $\beta$ pathway.

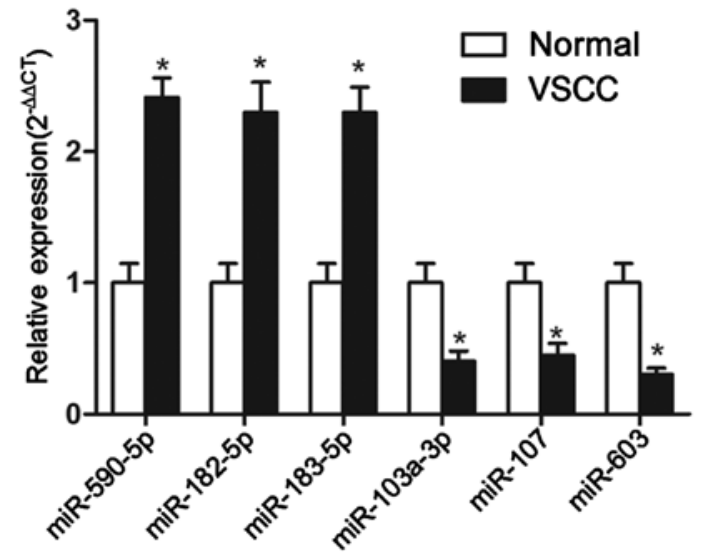

Figure 3. RT-qPCR-determined expression levels of selected miRNAs. miR-590-5p, miR-182-5p and miR-183-5p were upregulated in VSCC; miR-603, miR-103a-3p and miR-107 were downregulated in VSCC. ${ }^{*} \mathrm{P}<0.05$.

TGF- $\beta$-specific receptors including TGF $\beta$ RII, which plays a role in cell growth and carcinogenesis. Smad4 is a major transducer of intracellular signals of the TGF- $\beta$ pathway. TGFßRII has been shown to play roles in tumour invasion and metastasis in several types of cancers. Ganapathy et al showed that TGF $\beta$ RII is downregulated in HaCaT cells and found that TGF $\beta$ RII inhibits metastasis and progression of late-stage tumour cells (26). The overexpression of TGF $\beta$ RII inhibits cell growth in cancer (27). Additionally, TGF $\beta$ RII has also been found to be progressively lost in oral and skin SCC (28). However, the role of TGF $\beta$ RII in VSCC is unknown, and our research showed that TGF $\beta$ RII is underexpressed in vulvar carcinoma.

We conducted functional studies in A431 cells, which have previously been used for miRNA research. Alanazi et al found that some miRNAs (miR-663, miR-499-5p, miR-494, miR-602, miR-2861, miR-675 and miR-3185) may have crucial functions in A431 cell apoptosis through a process involving epidermal growth factor (EGF) involvement (29). In addition, miR-21 has been shown to promote the proliferation of A431 cells (30). In the present study, we transfected
Table V. Association between expression of miR-590-5p and clinical pathology of the VSCC cases.

\begin{tabular}{|c|c|c|c|c|}
\hline \multirow[b]{2}{*}{ Variables } & \multirow[b]{2}{*}{ Total } & \multicolumn{2}{|c|}{ miR-590-5p } & \multirow[b]{2}{*}{ P-value } \\
\hline & & Low & High & \\
\hline \multicolumn{5}{|c|}{ Age (years) } \\
\hline $25-69$ & 18 & 15 & 3 & 0.571 \\
\hline $70-85$ & 12 & 8 & 4 & \\
\hline \multicolumn{5}{|c|}{ Differentiation } \\
\hline Well & 14 & 6 & 8 & 0.961 \\
\hline Moderate & 12 & 6 & 6 & \\
\hline Poor & 4 & 1 & 3 & \\
\hline \multicolumn{5}{|c|}{ Vascular invasion } \\
\hline Yes & 5 & 1 & 4 & 0.903 \\
\hline No & 25 & 9 & 16 & \\
\hline \multicolumn{5}{|c|}{ Lymph node metastasis } \\
\hline No & 25 & 1 & 24 & $0.011^{\mathrm{a}}$ \\
\hline Yes & 5 & 3 & 2 & \\
\hline \multicolumn{5}{|c|}{ FIGO stage } \\
\hline I & 12 & 2 & 10 & 0.961 \\
\hline II & 13 & 4 & 9 & \\
\hline III & 5 & 1 & 4 & \\
\hline \multicolumn{5}{|c|}{ Tumor diameter $(\mathrm{cm})$} \\
\hline $0.3-2.5$ & 12 & 5 & 7 & 0.995 \\
\hline $2.6-4.0$ & 10 & 5 & 5 & \\
\hline $4.1-20.0$ & 8 & 3 & 5 & \\
\hline \multicolumn{5}{|c|}{ Depth of invasion (mm) } \\
\hline $0.0-4.0$ & 11 & 5 & 6 & 0.971 \\
\hline $4.1-8.0$ & 9 & 4 & 5 & \\
\hline $8.1-40.0$ & 10 & 3 & 7 & \\
\hline
\end{tabular}

${ }^{\mathrm{a}} \mathrm{P}<0.05$ 
Table VI. Putative mRNA targets for miR-590-5p.

\begin{tabular}{|c|c|}
\hline Name & Putative mRNA targets \\
\hline hsa-miR-590-5p & AIM1L \\
\hline hsa-miR-590-5p & ARMCX1 \\
\hline hsa-miR-590-5p & BAHD1 \\
\hline hsa-miR-590-5p & BEST3 \\
\hline hsa-miR-590-5p & BOLL \\
\hline hsa-miR-590-5p & BTK \\
\hline hsa-miR-590-5p & CCL1 \\
\hline hsa-miR-590-5p & CCL20 \\
\hline hsa-miR-590-5p & CNTFR \\
\hline hsa-miR-590-5p & DAG1 \\
\hline hsa-miR-590-5p & ELF2 \\
\hline hsa-miR-590-5p & FASLG \\
\hline hsa-miR-590-5p & GLCCI1 \\
\hline hsa-miR-590-5p & GPR64 \\
\hline hsa-miR-590-5p & IL12A \\
\hline hsa-miR-590-5p & ITGB8 \\
\hline hsa-miR-590-5p & JHDM1D \\
\hline hsa-miR-590-5p & LATS 1 \\
\hline hsa-miR-590-5p & MATN2 \\
\hline hsa-miR-590-5p & MRPL9 \\
\hline hsa-miR-590-5p & MSH2 \\
\hline hsa-miR-590-5p & NELL2 \\
\hline hsa-miR-590-5p & NFIB \\
\hline hsa-miR-590-5p & NTF3 \\
\hline hsa-miR-590-5p & PCBP2 \\
\hline hsa-miR-590-5p & PCSK6 \\
\hline hsa-miR-590-5p & PFKM \\
\hline hsa-miR-590-5p & PIK3R1 \\
\hline hsa-miR-590-5p & RBMS3 \\
\hline hsa-miR-590-5p & RBPJ \\
\hline hsa-miR-590-5p & RECK \\
\hline hsa-miR-590-5p & S100A10 \\
\hline hsa-miR-590-5p & SKI \\
\hline hsa-miR-590-5p & SLC2A4RG \\
\hline hsa-miR-590-5p & SPRY1 \\
\hline hsa-miR-590-5p & SPRY2 \\
\hline hsa-miR-590-5p & ST3GAL6 \\
\hline hsa-miR-590-5p & STAG2 \\
\hline hsa-miR-590-5p & TAGAP \\
\hline hsa-miR-590-5p & TBX2 \\
\hline hsa-miR-590-5p & TGF $\beta 2$ \\
\hline hsa-miR-590-5p & TGF $\beta 1$ \\
\hline hsa-miR-590-5p & TNFRSF11B \\
\hline hsa-miR-590-5p & TOPORS \\
\hline hsa-miR-590-5p & WNK3 \\
\hline hsa-miR-590-5p & WWP1 \\
\hline hsa-miR-590-5p & XKR6 \\
\hline hsa-miR-590-5p & ZCCHC3 \\
\hline hsa-miR-590-5p & ZNF367 \\
\hline hsa-miR-590-5p & ZNF704 \\
\hline
\end{tabular}
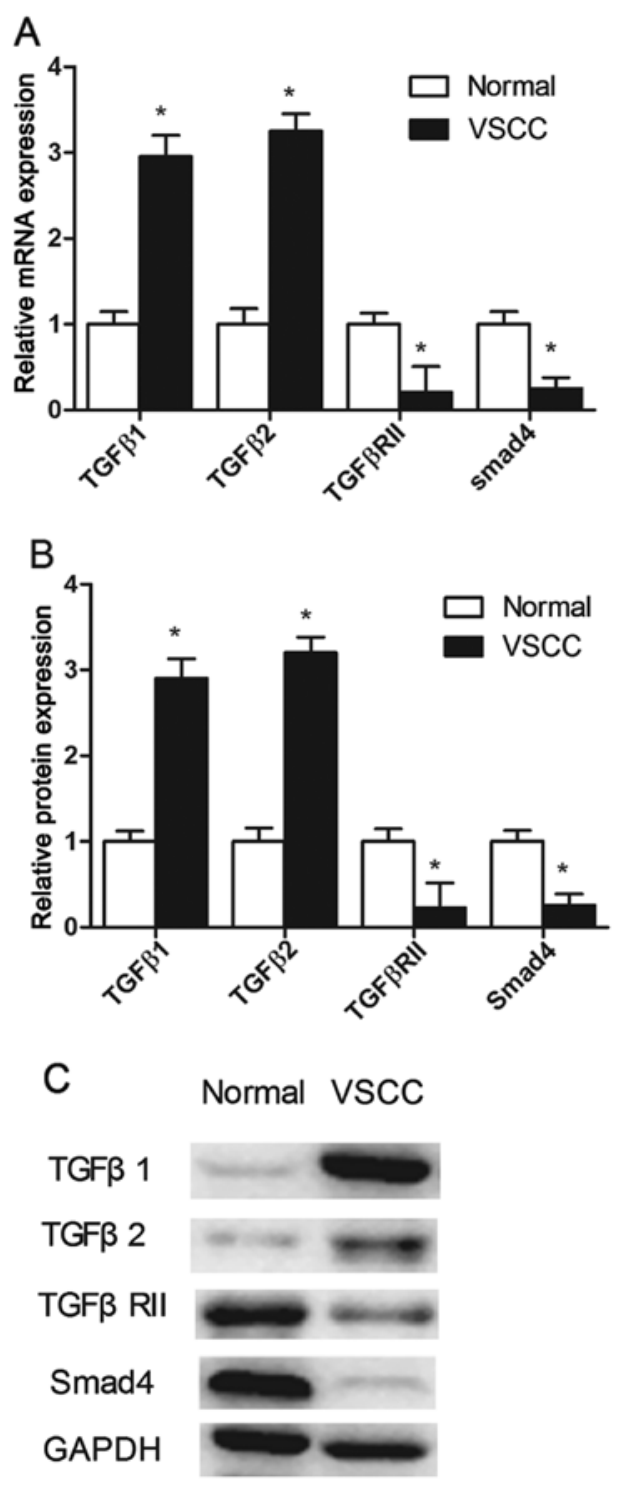

Figure 4. Expression of TGF $\beta 1$, TGF $\beta 2$, TGF $\beta$ RII and Smad4 in VSCC samples. (A) mRNA expression levels of TGF $\beta 1$, TGF $\beta 2$, TGF $\beta$ RII and Smad4 in 30 pairs of VSCC and corresponding normal tissue samples. (B and C) Western blot analysis was conducted with the indicated antibodies. GAPDH was used as the internal control. ${ }^{*} \mathrm{P}<0.05$.

the miR-590-5p mimic into A431 cells, and after transfection, the endogenous level of miR-590-5p was upregulated. The MTT assay revealed that cell proliferation was markedly increased (Fig. 5D) and that TGF $\beta$ RII was downregulated (Fig. 5A-C). The Transwell assay results suggested that miR-590-5p induced cell migration (Fig. 6A). We also explored changes in cell cycle progression, which is an essential step in carcinogenesis. The FCM results indicated that the upregulation of miR-590-5p promoted the G1-to-S cell cycle transition in the A431 cells (Fig. 7A). Our results provide novel information regarding the roles of miR-590-5p in tumourigenesis. Moreover, we used siRNA to successfully block TGF $\beta$ RII expression and obtained results that were similar to those obtained after the overexpression of miR-590-5p. We found that miR-590-5p exerted an oncogenic function in vulvar cancer. Based on our results, we hypothesize that 

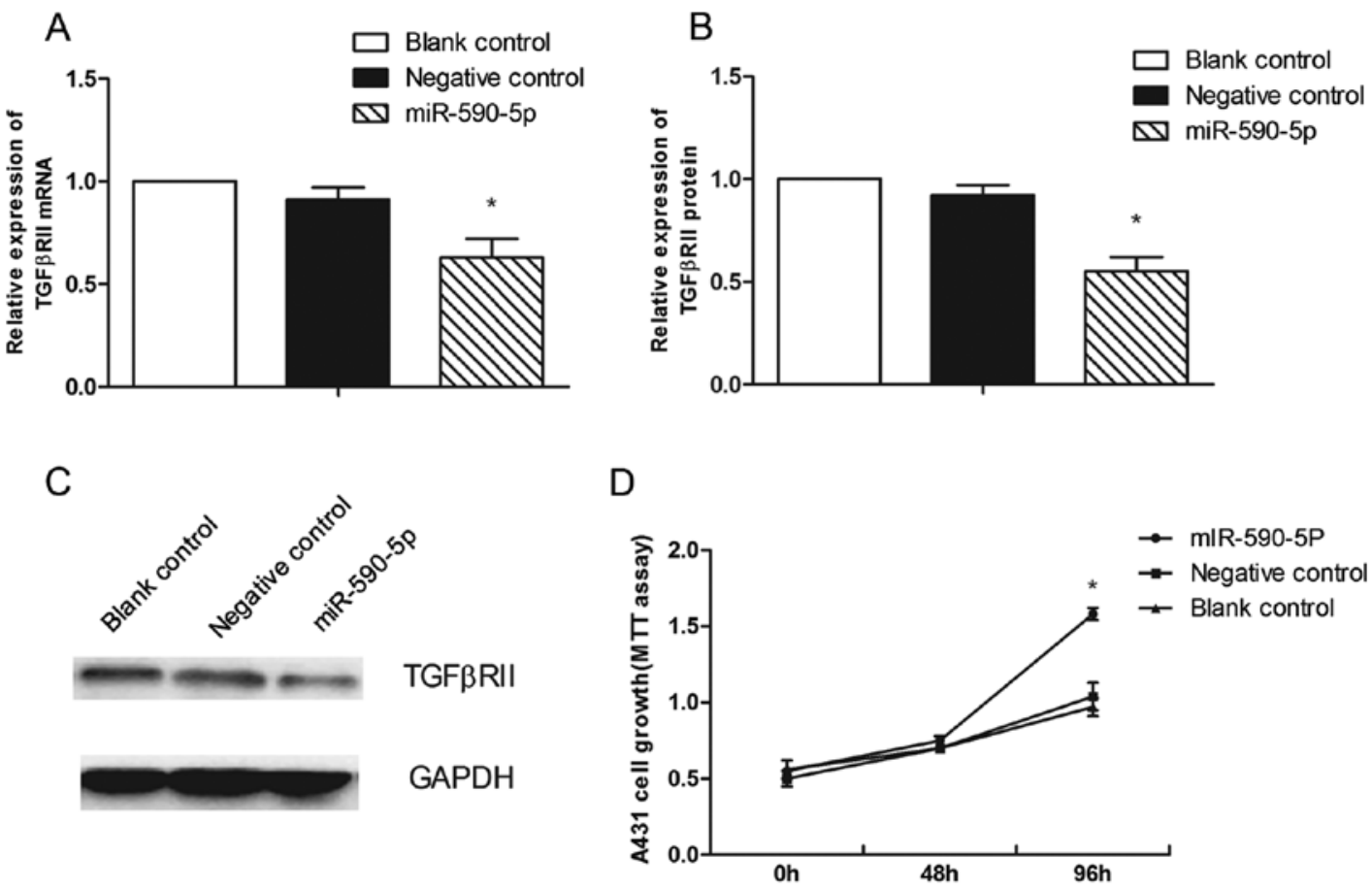

Figure 5. miR-590-5p plays an oncogenic role in A431 cells. miR-590-5p downregulated the mRNA (A) and protein (B and C) expression levels of TGF 3 RII (D) After $96 \mathrm{~h}$, upregulation of miR-590-5p by transfection with the miR-590-5p mimic promoted cell proliferation compared with transfection with the miRNA negative control. ${ }^{*} \mathrm{P}<0.05$.

A

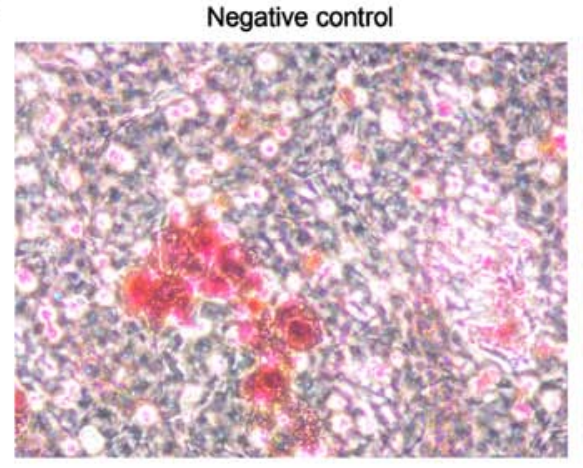

B

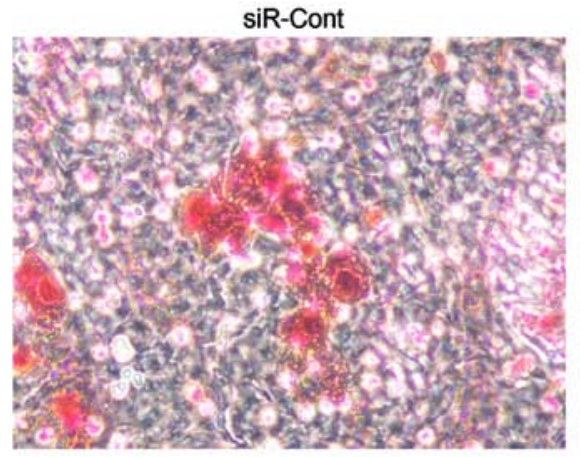

miR-590-5p

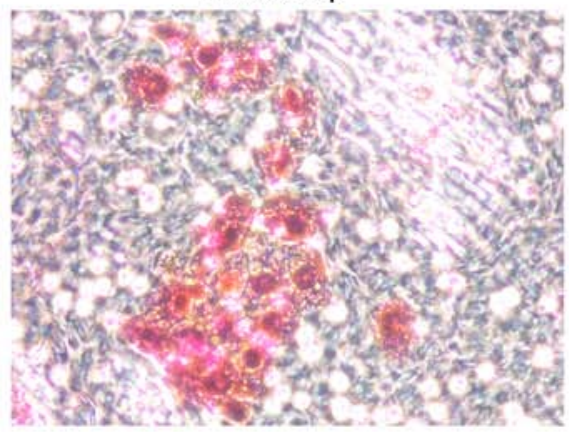

siR-TGFRßII

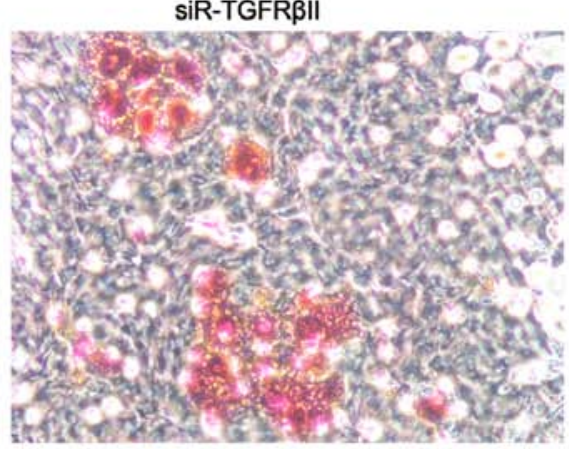

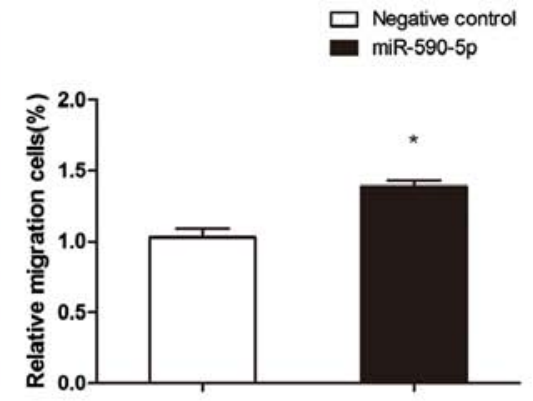

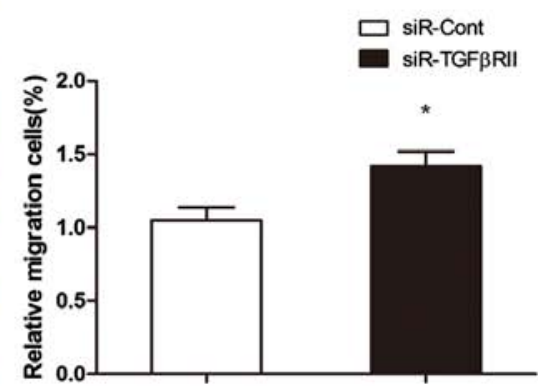

Figure 6. miR-590-5p and TGFßRII regulate A431 migration. (A) Overexpression of miR-590-5p promoted cell migration. (B) Knockdown of TGF $3 R$ II by siRNA promoted cell migration. ${ }^{*} \mathrm{P}<0.05$.

miR-590-5p interferes with the TGF- $\beta$ pathway to regulate cell growth and induce carcinogenesis.

The present study has some limitations. First, vulvar cancer is a rare disease; thus, the number of clinical samples in our study was relatively low, and more microarray studies on vulvar cancer are needed to obtain larger data sets. We did not conduct a dual luciferase reporter assay in our study since it was performed previously (13). We found that miR-590-5p, TGF $\beta 1$ and TGF $\beta 2$ were all upregulated in VSCC tissues, which suggests that miRNAs other than miR-590-5p may be 

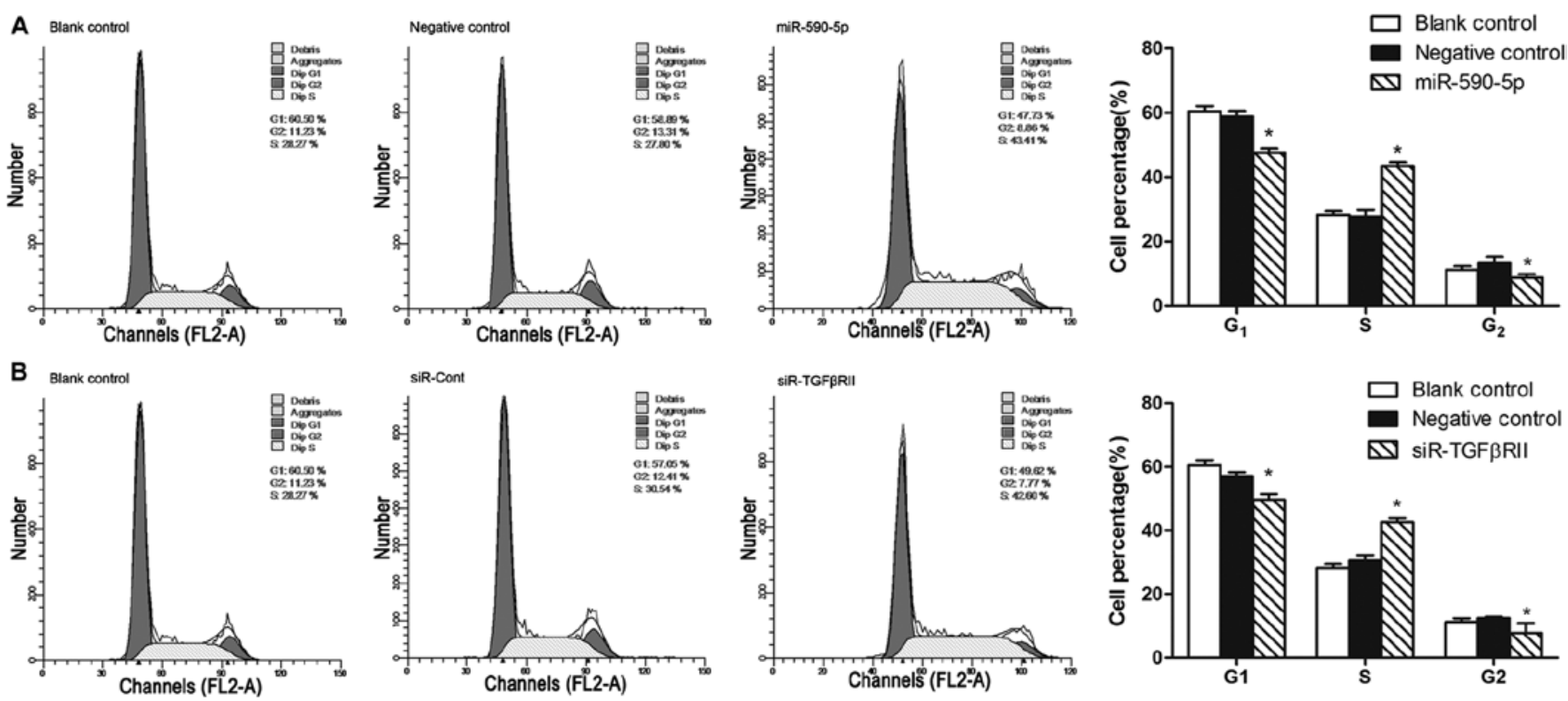

Figure 7. miR-590-5p and TGFßRII regulate the cell cycle of A431 cells. (A) Overexpression of miR-590-5p promoted G1-to-S phase transition. (B) Knockdown of TGF $\beta$ RII decreased $\mathrm{G}$ phase arrest. " $\mathrm{P}<0.05$.
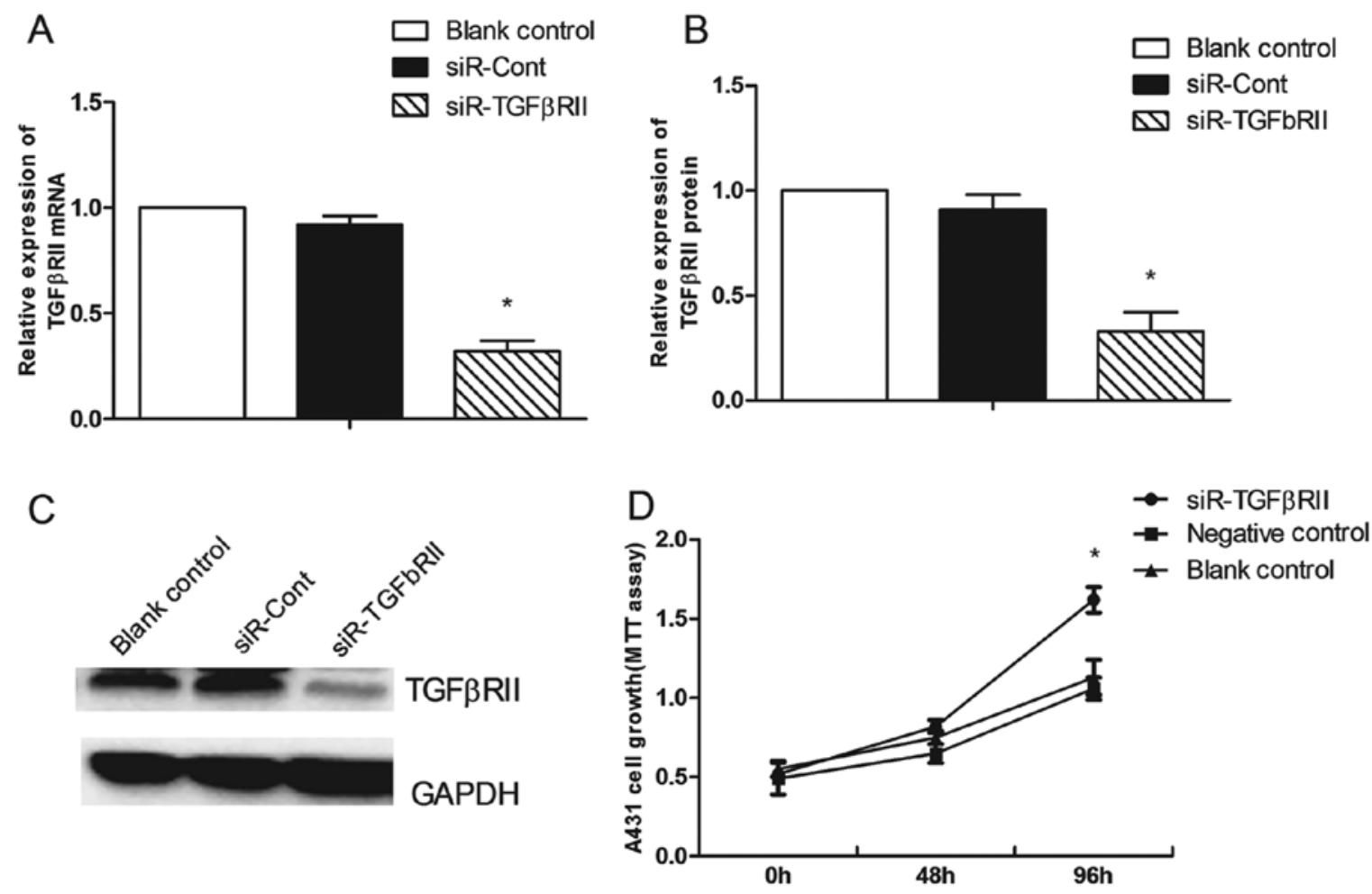

Figure 8. TGF $\beta$ RII regulates A431 cell proliferation. siRNA targeting TGF $\beta$ RII suppressed the mRNA (A) and protein (B and C) expression levels of TGF $\beta$ RII. (D) Knockdown of TGFßRII by siRNA increased the cell proliferation rate at $96 \mathrm{~h}$ after transfection. ${ }^{*} \mathrm{P}<0.05$.

responsible for the upregulation of TGF $\beta 1$ and TGF $\beta 2$ because miRNAs typically decrease the expression of their target mRNAs. However, some miRNAs have also been reported to increase the expression of target genes. For example, miR-373 increases the expression of its target gene, E-cadherin (31). Therefore, further assays need to be performed to determine the targets of miR-590-5p. The relationship between miR-182-5p and Smad4 in VSCC remains to be investigated.
In conclusion, we determined the miRNA expression profile in VSCC and evaluated the expression of a subset of miRNAs by microarray. Target prediction and functional analysis suggested that miR-590-5p is involved in the tumourigenesis of VSCC as the upregulation of miR-590-5p was found to be associated with lymphatic metastasis. Furthermore, the present investigation showed that miR-590-5p plays an oncogenic role in VSCC by promoting cell proliferation and 
migration as well as the G1-S transition through the manipulation of TGF $\beta$ RII expression. These findings suggest that miR-590-5p may be a critical therapeutic target in VSCC.

\section{Acknowledgements}

We thank Tao Zhang for his invaluable technical assistance.

\section{References}

1. Pathak D, Agrawal S and Dhali TK: Prevalences of and risk factors for vulvar diseases in Nepal: A hospital-based study. Int J Dermatol 50: 161-167, 2011.

2. Akhtar-Danesh N, Elit L and Lytwyn A: Trends in incidence and survival of women with invasive vulvar cancer in the United States and Canada: A population-based study. Gynecol Oncol 134: 314-318, 2014

3. Dittmer C, Katalinic A, Mundhenke C, Thill M and Fischer D: Epidemiology of vulvar and vaginal cancer in Germany. Arch Gynecol Obstet 284: 169-174, 2011.

4. Judson PL, Habermann EB, Baxter NN, Durham SB and Virnig BA: Trends in the incidence of invasive and in situ vulvar carcinoma. Obstet Gynecol 107: 1018-1022, 2006.

5. Chen CZ, Li L, Lodish HF and Bartel DP: MicroRNAs modulate hematopoietic lineage differentiation. Science 303: 83-86, 2004.

6. Sharma A, Kumar M, Aich J, Hariharan M, Brahmachari SK Agrawal A and Ghosh B: Posttranscriptional regulation of interleukin-10 expression by hsa-miR-106a. Proc Natl Acad Sci USA 106: 5761-5766, 2009.

7. Ambros V: The functions of animal microRNAs. Nature 431: 350-355, 2004

8. de Melo Maia B, Lavorato-Rocha AM, Rodrigues LS, Coutinho-Camillo CM, Baiocchi G, Stiepcich MM, Puga R, de A Lima L, Soares FA and Rocha RM: microRNA portraits in human vulvar carcinoma. Cancer Prev Res (Phila) 6: 1231-1241, 2013.

9. Pecorelli S: Revised FIGO staging for carcinoma of the vulva, cervix, and endometrium. Int J Gynaecol Obstet 105: 103-104, 2009.

10. Chen C, Ridzon DA, Broomer AJ, Zhou Z, Lee DH, Nguyen JT, Barbisin M, Xu NL, Mahuvakar VR, Andersen MR, et al: Real-time quantification of microRNAs by stem-loop RT-PCR. Nucleic Acids Res 33: e179, 2005.

11. Li Y, Wang F, Xu J, Ye F, Shen Y, Zhou J, Lu W, Wan X, Ma D and Xie X: Progressive miRNA expression profiles in cervical carcinogenesis and identification of HPV-related target genes for miR-29. J Pathol 224: 484-495, 2011.

12. Chen ZL, Zhao XH, Wang JW, Li BZ, Wang Z, Sun J, Tan FW, Ding DP, Xu XH, Zhou F, et al: microRNA-92a promotes lymph node metastasis of human esophageal squamous cell carcinoma via E-cadherin. J Biol Chem 286: 10725-10734, 2011.

13. Jiang X, Xiang G, Wang Y, Zhang L, Yang X, Cao L, Peng H, Xue $P$ and Chen D: MicroRNA-590-5p regulates proliferation and invasion in human hepatocellular carcinoma cells by targeting TGF- $\beta$ RII. Mol Cells 33: 545-551, 2012.

14. Hirata H, Ueno K, Shahryari V, Tanaka Y, Tabatabai ZL, Hinoda $Y$ and Dahiya R: Oncogenic miRNA-182-5p targets Smad4 and RECK in human bladder cancer. PLoS One 7: e51056, 2012.

15. Garzon R, Fabbri M, Cimmino A, Calin GA and Croce CM: MicroRNA expression and function in cancer. Trends Mol Med 12: 580-587, 2006.

16. Eulalio A, Mano M, Dal Ferro M, Zentilin L, Sinagra G, Zacchigna S and Giacca M: Functional screening identifies miRNAs inducing cardiac regeneration. Nature 492: 376-381, 2012.
17. Watson JA, Bryan K, Williams R, Popov S, Vujanic G, Coulomb A, Boccon-Gibod L, Graf N, Pritchard-Jones K and O'Sullivan M: miRNA profiles as a predictor of chemoresponsiveness in Wilms' tumor blastema. PLoS One 8: e53417, 2013.

18. Chu Y, Ouyang Y, Wang F, Zheng A, Bai L, Han L, Chen Y and Wang H: MicroRNA-590 promotes cervical cancer cell growth and invasion by targeting CHL1. J Cell Biochem 115: 847-853, 2014.

19. Xiao X, Tang C, Xiao S, Fu C and Yu P: Enhancement of proliferation and invasion by microRNA-590-5p via targeting PBRM1 in clear cell renal carcinoma cells. Oncol Res 20: 537-544, 2013.

20. Ekhteraei-Tousi S, Mohammad-Soltani B, Sadeghizadeh M, Mowla SJ, Parsi S and Soleimani M: Inhibitory effect of hsa-miR-590-5p on cardiosphere-derived stem cells differentiation through downregulation of TGFB signaling. J Cell Biochem 116: 179-191, 2015.

21. Shan X, Miao Y, Fan R, Qian H, Chen P, Liu H, Yan X, Li J and Zhou F: MiR-590-5P inhibits growth of HepG2 cells via decrease of S100A10 expression and Inhibition of the Wnt pathway. Int J Mol Sci 14: 8556-8569, 2013.

22. Ji Q, Liu X, Han Z, Zhou L, Sui H, Yan L, Jiang H, Ren J, Cai J and Li Q: Resveratrol suppresses epithelial-to-mesenchymal transition in colorectal cancer through TGF- $\beta 1 /$ Smads signaling pathway mediated Snail/E-cadherin expression. BMC Cancer 15: 97, 2015.

23. Guo W, Zhang M, Shen S, Guo Y, Kuang G, Yang Z and Dong Z: Aberrant methylation and decreased expression of the TGF- $\beta /$ Smad target gene FBXO32 in esophageal squamous cell carcinoma. Cancer 120: 2412-2423, 2014.

24. Goto N, Hiyoshi H, Ito I, Iida K, Nakajima Y, Nagasawa K and Yanagisawa J: Identification of a novel compound that suppresses breast cancer invasiveness by inhibiting transforming growth factor- $\beta$ signaling via estrogen receptor $\alpha$. J Cancer 5: 336-343, 2014.

25. Ischenko I, Liu J, Petrenko O and Hayman MJ: Transforming growth factor-beta signaling network regulates plasticity and lineage commitment of lung cancer cells. Cell Death Differ 21: 1218-1228, 2014

26. Ganapathy A, Paterson IC, Prime SS, Eveson JW, Pring M, Price N, Threadgold SP and Davies M: TGF- $\beta$ inhibits metastasis in late stage human squamous cell carcinoma of the skin by a mechanism that does not involve Id1. Cancer Lett 298: 107-118, 2010.

27. Deacu E, Mori Y, Sato F, Yin J, Olaru A, Sterian A, Xu Y, Wang S, Schulmann K, Berki A, et al: Activin type II receptor restoration in ACVR2-deficient colon cancer cells induces transforming growth factor-beta response pathway genes. Cancer Res 64: 7690-7696, 2004.

28. Paterson IC, Matthews JB, Huntley S, Robinson CM, Fahey M, Parkinson EK and Prime SS: Decreased expression of TGF-beta cell surface receptors during progression of human oral squamous cell carcinoma. J Pathol 193: 458-467, 2001.

29. Alanazi I, Hoffmann P and Adelson DL: MicroRNAs are part of the regulatory network that controls EGF induced apoptosis, including elements of the JAK/STAT pathway, in A431 cells. PLoS One 10: e0120337, 2015.

30. Li X, Huang K and Yu J: Inhibition of microRNA-21 upregulates the expression of programmed cell death 4 and phosphatase tensin homologue in the A431 squamous cell carcinoma cell line. Oncol Lett 8: 203-207, 2014.

31. Place RF, Li LC, Pookot D, Noonan EJ and Dahiya R: MicroRNA-373 induces expression of genes with complementary promoter sequences. Proc Natl Acad Sci USA 105: 1608-1613, 2008. 